J. Perinat. Med. 15 (1987) 137

\section{Heterogeneity of congenital primary hypothyroidism: The importance of thyroid scintigraphy*}

\author{
Edgar J. Schoen', Leo V. dos Remedios' ${ }^{2}$, and Martha Backstrom ${ }^{1}$
}

${ }^{1}$ Department of Pediatrics and ${ }^{2}$ Department of Nuclear Medicine, Kaiser Permanente Medical Center, Oakland, California, U.S. A.

\section{Introduction}

Neonatal screening for primary congenital hypothyroidism has become widespread; it is estimated that 7 to 9 million newborn infants are tested yearly throughout the industrialized world [4]. Although an elevated serum thyrotropin (TSH) level is the criterion for diagnosing this disorder, the predominant screening method in the United States is to first determine thyroxine $\left(\mathrm{T}_{4}\right)$ from bloodspots on filter-paper, then to obtain follow-up TSH levels in infants with the lowest $5 \%$ to $10 \%$ of $\mathrm{T}_{4}$ levels. The combination of low $\mathrm{T}_{4}$ and high TSH leads to the diagnosis of congenital primary hypothyroidism and to treatment with thyroid hormone preparations after the initial laboratory results are confirmed by serum testing. In California, neonatal thyroid screening began in 1980 and about 400,000 infants are tested yearly. As in most states and countries, once the diagnosis is confirmed by low $\mathrm{T}_{4}$ with high TSH no further testing is mandated to confirm the etiology, severity, or prognosis of the disease. One cannot distinguish between patients having transient hypothyroidism, dyshormonogenesis, transient hyperthyrotropinemia, ectopic thyroid, or complete athyrosis. Since athyrotic cretinism and other severe forms of congenital

* Abstract published in Clinical Research 1984; 32: 95 A in conjunction with presentation at the Western Society for Pediatric Research meeting, Carmel, California, February 7-10, 1984.

\section{Curriculum vitae}

EDgaR J. SCHOEN, born 1925, received M.D. degree, New York University College of Medicine 1948. Pediatric Residency and Endocrine Fellowship, Massachusetts General Hospital, Boston 194954. Fellowship, Steroid Biochemistry, University of Utah 1960-61. Since 1954 Pediatrician and Pediatric

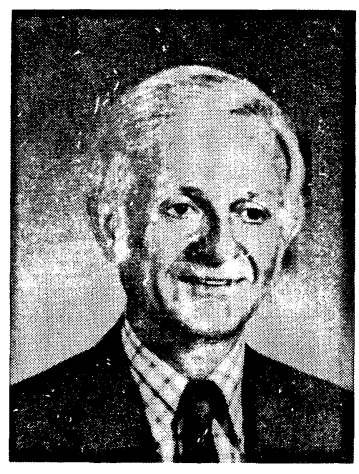
Endocrinologist, Department of Pediatrics, Kaiser Permanente Medical Center, Oakland, California (since 1966 Chief at the Department of Pediatrics). Since 1960 Assistant Clinical Professor of Pediatrics University of California San Francisco School of Medicine. Main fields of interest: pediatric endocrinology, newborn screening, pediatric health care delivery and administration.

hypothyroidism require a lifetime of thyroid therapy, it is important to distinguish these from milder and transient disease or from dyshormonogenesis as early as possible. Thyroid scintigraphy is one of the most effective aids in the specific differential diagnosis of primary congenital hypothyroidism. We believe that scintigraphy and other tests aimed at clarifying the diagnosis should be performed in all infants with this condition before starting thyroid treatment. We report our experience in 46 infants with congenital hypothyroidism, 40 of which had thyroid scintigraphy. 


\section{Materials and methods}

In the 6.6 years between September 1, 1978 and March 31, 1985, 166,300 newborn infants born at hospitals of the Northern California Kaiser Permanente Medical Care Program were screened for congenital hypothyroidism. Fullterm infants with $\mathrm{T}_{4}$ levels more than two standard deviations ( $>2 \mathrm{SD}$ ) below the mean on filter-paper bloodspot tests also had TSH tested from these spots. All premature infants (birth weight $<2,500 \mathrm{~g}$ ) and all infants in intensive care nurseries received the TSH testing. Adding these groups to the low $\mathrm{T}_{4}$ group of full-term infants resulted in TSH testing for $7.3 \%$ of all newborns (12,060 infants). In infants with TSH greater than $25 \mu \mathrm{IU} / \mathrm{ml}$, serum testing was repeated. Both $\mathrm{T}_{4}$ and TSH were assayed from the filter-paper bloodspots by double isotope radioimmunoassay using reagents supplied by Nichols Institute Reference Laboratories, Los Angeles, California; follow-up on presumptive positive tests for $\mathrm{T}_{4}$ and TSH used the same method in fresh serum specimens. Triiodothyronine $\left(T_{3}\right)$ uptake was assayed by the talc method of LIN and Dos REMEDIOs [11]. Technetium-99m imaging (Tc-99m) was performed by administering $200 \mu \mathrm{Ci}$ as pertechnetate intravenously and imaging with a pinhole collimator in 20 minutes. Iodine-123 (I-123) imaging was done by administering $5 \mu \mathrm{Ci}$ orally as sodium iodide and imaging with a pinhole collimator in 24 hours. Use of Tc-99m and I-123 imaging in newborn infants, including techniques and absorbed radiation dose, have recently been described [7].

Table I. Pretreatment blood $\mathrm{T}_{4}$ and TSH level in relation to thyroid scintigraphy results in 40 infants with primary congenital hypothyroidism, Sept. 1, 1978-March 31, 1985.

\begin{tabular}{|c|c|c|c|c|c|c|c|c|}
\hline \multicolumn{3}{|l|}{ Athyrosis } & \multicolumn{3}{|c|}{ Ectopic or Hypoplastic Thyroid } & \multicolumn{3}{|c|}{ Normal Gland } \\
\hline $\begin{array}{l}\text { Case no. } \\
\text { (Tc or I) }\end{array}$ & $\begin{array}{l}\mathrm{T}_{4} \\
(\mu \mathrm{g} / \mathrm{dL})\end{array}$ & $\begin{array}{l}\text { TSH } \\
(\mu \mathrm{IU} / \mathrm{mL})\end{array}$ & $\begin{array}{l}\text { Case no. } \\
\text { (Tc or I) }\end{array}$ & $\begin{array}{l}\mathrm{T}_{4} \\
(\mu \mathrm{g} / \mathrm{dL})\end{array}$ & $\begin{array}{l}\text { TSH } \\
(\mu \mathrm{IU} / \mathrm{mL})\end{array}$ & $\begin{array}{l}\text { Case no. } \\
\text { (Tc or I) }\end{array}$ & $\begin{array}{l}\mathrm{T}_{4} \\
(\mu \mathrm{g} / \mathrm{dL})\end{array}$ & $\begin{array}{l}\text { TSH } \\
(\mu \mathrm{IU} / \mathrm{mL})\end{array}$ \\
\hline 12 (I) & 5.7 & 250 & $11(\mathrm{Tc})$ & 7.6 & 222 & $5(\mathrm{Tc})$ & 6.7 & 77 \\
\hline $13(\mathrm{Tc})$ & 2.4 & 218 & 20 (I) & 1.6 & 243 & $6(\mathrm{Tc})$ & 2.4 & 171 \\
\hline 14 (I) & 1.0 & 167 & $30(\mathrm{Tc})$ & 9.3 & 151 & $7(\mathrm{Tc})$ & 4.0 & 308 \\
\hline $15(\mathrm{Tc})$ & 1.0 & 363 & 42 (I) & 11.4 & 195 & $8(\mathrm{Tc})$ & 8.5 & 178 \\
\hline $17(\mathrm{Tc})$ & 2.3 & 1500 & 43 (I) & 3.5 & 602 & $10(\mathrm{Tc})$ & 10.3 & 84 \\
\hline 21 (I) & 1.8 & 311 & 44 (I) & 7.2 & 171 & $16(\mathrm{Tc})$ & 11.3 & 67 \\
\hline 24 (I) & 0.9 & 231 & 46 (I) & 2.2 & 306 & 19 (I) & 4.4 & 231 \\
\hline 27 (I) & 1.9 & 230 & & & & $22(\mathrm{I})$ & 2.9 & 277 \\
\hline 29 (I) & 1.1 & 479 & & & & 23 (I) & 1.1 & 350 \\
\hline 32 (I) & 1.9 & 318 & & & & 25 (I) & 0.8 & 408 \\
\hline 35 (I) & 6.0 & 350 & & & & $26(\mathrm{I})$ & 8.7 & 246 \\
\hline 36 (I) & 0.3 & 754 & & & & 28 (I) & 4.1 & 316 \\
\hline 38 (I) & 2.3 & 343 & & & & 31 (I) & 7.0 & 155 \\
\hline 39 (I) & 5.3 & 691 & & & & 33 (I) & 1.9 & 447 \\
\hline \multirow[t]{4}{*}{$41(\mathrm{I})$} & 1.8 & 391 & & & & 34 (I) & 6.6 & 214 \\
\hline & & & & & & 37 (I) & 5.9 & 200 \\
\hline & & & & & & 40 (I) & 9.2 & 137 \\
\hline & & & & & & 45 (I) & 2.9 & 358 \\
\hline \multicolumn{9}{|l|}{ No cases } \\
\hline $15(37 \%)$ & & & $7(18 \%)$ & & & $18(45 \%)$ & & \\
\hline Mean & 2.0 & 433 & & 5.0 & 270 & & 5.1 & 235 \\
\hline Range & $1.0-6.0$ & $131-1500$ & & $1.6-9.3$ & $151-602$ & & $0.8-11.3$ & $67-447$ \\
\hline
\end{tabular}

$\mathrm{Tc}=$ technetium-99m; I = iodine-123 
In the 46 infants with congenital hypothyroidism, the procedure changed as the importance of thyroid scintigraphy was realized. Early in the study, in the few scans performed, Tc-99m was used; most recently, we have preferred to use I-123 in scintigraphy [7].

Clinical and laboratory follow-up evaluation of all cases in our Northern California facilities was monitored through a regional center having a medical director (E. J. S.) and full-time nurse specialist (M. B.), allowing consistency of diagnosis and management and prompt communication with the patient's primary physician.

\section{Results}

Of the 166,300 infants screened for $\mathrm{T}_{4}, 12,060$ $(7.3 \%)$ were tested for TSH. Presumptive positive tests (low $\mathrm{T}_{4}$, initial TSH more than $25 \mu \mathrm{IU} / \mathrm{ml})$ were found in $280(1: 655), 46$ $(1: 3615)$ of which were diagnosed as having primary congenital hypothyroidism by demonstrating persistently high TSH levels at repeat serum testing. Of these 46 patients, data for 40 who had thyroid scintigraphy performed are summarized in table I. Eighteen (45\%) of the 40 infants had normal thyroid scintigrams, 15 (37\%) showed absence of the thyroid gland, and seven (18\%), ectopic or hypoplastic glands. Although the athyrotic infants had significantly lower mean $\mathrm{T}_{4}$ and higher mean TSH values than those with ectopic or normal-appearing thyroid glands $(p<0.05)$, there was a wide range within each of the three groups, so that no conclusion regarding classification could be drawn in an individual case. All infants had the diagnosis confirmed and scintigraphy performed before starting therapy at the mean age of 14 days. One infant had Down syndrome ( $\mathrm{T}_{4}$ 2.1, TSH 143, no scintigram performed). Two patients were twins: twin A had a normal scintigram and relatively mild disease, in which the TSH level rose from 67 to $136 \mu \mathrm{IU} / \mathrm{ml}$ in three weeks; twin B had athyrosis at scintigraphy with a TSH level of $1,500 \mu \mathrm{IU} / \mathrm{ml}$. One patient had dysmorphic features suggesting
Johanson-Blizzard syndrome [8] with subsequent marked developmental delay and short stature in spite of adequate thyroid replacement. Six children of hyperthyroid mothers had received propylthiouracil during pregnancy. All these infants had low $T_{4}$ values with slightly elevated TSH (between $25-80 \mu \mathrm{IU} / \mathrm{ml}$ ), but in all instances repeat serum studies before age 14 days showed spontaneous return of $\mathrm{T}_{4}$ and TSH values to normal; none of these is included in our series of hypothyroid infants. During the first two years of the study before the value of scintigraphy was recognized, only two of the six cases had this test; 38 of the subsequent 40 cases had scintigraphy.

\section{Discussion}

Thyroid scintigraphy is a valuable technique for elucidating the specific diagnosis in congenital primary hypothyroidism, and we believe this imaging process should be performed in every case before starting what might be a lifetime of thyroid therapy. As pointed out by HEYMan, et al. [6], thyroid uptake and scintigrams differentiate athyrotic and ectopic hypothyroidism from other causes of abnormal thyroid function in the newborn infant and we agree with these authors that I-123 is superior to Tc-99m for study of the thyroid gland in neonates. Moreover, this test need not delay diagnosis and treatment; in our series of 40 cases, the mean infant age at scintigraphy was 12 days and therapy was begun by the mean age of 14 days, well below the age reported in published series from other programs $[5,9,10,12,14]$. The longer delay in performing scintigraphy in the series of HEYMAN, et al. [6] perhaps represents difficulty in coordinating the multistate New England Regional Hypothyroid Screening Program, from which the cases were drawn. This emphasizes the discrepancy between the diagnostic and follow-up aspects of a large screening program and is a point in favor of smaller programs in which early, accurate diagnosis and prompt treatment can be more easily coordinated [15]. 
Eighteen of our 40 patients were found to have apparently normal thyroid glands at scintigraphy compared with six of the 16 cases of HEYMAN, et al. [6]. By contrast, earlier international studies suggested that thyroid dysgenesis was the predominant factor in congenital hypothyroidism. The Second International Conference on Neonatal Thyroid Screening [4] reported that $90 \%$ of primary congenital hypothyroidism is caused by thyroid dysgenesis, about two thirds being thyroid ectopia and one third agenesis. Of the 48 infants having scintigraphy in the Toronto series of PRICE, et al. [14], 30 were described as having dysgenesis (athyrotic, ectopic, or hypoplastic). There are several possible reasons why the recent studies in this country find an anatomically normal or goitrous gland in a much larger percentage of cases. First, the etiology and incidence of the condition may differ from country to country. Second, improved techniques for thyroid scintigraphy are likely to demonstrate thyroid tissue in the neonate in instances when less advanced methods show no gland. Thus, false results would favor agenesis, resulting in a misleadingly high estimate. The absence of goitrous glands in our series compared with others [6, 14] deserves mention. Standards for normal thyroid gland size in the newborn are lacking. In the presence of thyroid tissue in the normal location without a clinically enlarged thyroid gland, we have hesitated to diagnose goiter. Moreover, since our patients were treated at a significantly younger age than in the previous series mentioned [5, 6, 9, 10,12,14], it is conceivable that if therapy were delayed, in some of our patients a goiter might have developed. Continued experience in more patients, using newer improved techniques for thyroid scintigraphy, should settle the question of relative incidence of normal and dysgenetic glands in congenital hypothyroidism. Recent studies have suggested that ultrasonography and serum thyroglobulin measurements may be helpful in classifying congenital hypothyroidism $[2,3,13]$. Serial measurements of $T_{4}$, free $T_{4}, T_{3}$, and TSH may also aid in diagnosing borderline cases. In the absence of thyroid enlargement, correlation of these laboratory parameters with thyroid scintigraphy can be expected. For example, a minimal rise in TSH in conjunction with consistently normal or only slightly low $\mathrm{T}_{4}, \mathrm{~T}_{3}$, free $\mathrm{T}_{4}$, and thyroglobulin on serial measurements tends to make suspect a scintigram reflecting athyrosis. These correlations are well illustrated in our cases involving twins; the twin with athyrosis on a scintigram had very high and rising TSH $(1,500 \mu \mathrm{IU} / \mathrm{ml})$ and very low, falling $\mathrm{T}_{4}(0.7 \mathrm{ng} / \mathrm{ml})$, whereas the twin with a normal scintigram had much lower $\mathrm{TSH}$ (maximum, $143 \mu \mathrm{IU} / \mathrm{ml}$ ) and higher $\mathrm{T}_{4}$ $(11.3 \mathrm{ng} / \mathrm{ml})$.

Thyroid scintigraphy findings have clinical application in the decision to start and continue thyroid therapy. In proven athyrotic patients, continual treatment is necessary throughout life; the same is true in most patients with ectopic glands. In patients with normal-appearing thyroid glands at scintigraphy, the decision to treat varies in each case. In infants who show minimal laboratory evidence of congenital hypothyroidism, serial testing of serum for $\mathrm{T}_{4}$ and TSH for a few weeks might eliminate the need for treatment by demonstrating transient hypothyroidism with laboratory values returning to normal. In the presence of a normal scintigram, even if treatment is elected, therapy might be discontinued at an early age and the patient retested. In this group also, dyshormonogenesis, with its genetic implications, may occur.

The diagnosis of congenital hypothyroidism should be confirmed by detailed repeat and specific testing including thyroid scintigraphy before therapy is begun; this is necessary to avoid unnecessary thyroid treatment. In a screening program using an empirically selected low $\mathrm{T}_{4}$ level as the criterion for TSH testing, it is tempting to begin treatment before the diagnosis of primary hypothyroidism is confirmed by further diagnostic procedures. Although most large thyroid screening programs, California's included, have centralized, standardized laboratories with excellent quality control for screening procedures, the follow-up diagnostic testing and suhsequent clinical care are more diffuse and less well monitored. Ad- 
ministering thyroid hormone to normal infants in therapeutic amounts may not be entirely harmless. Excess amounts have untoward effects, including premature closure of cranial sutures, and the effect of unnecessary prolonged administration to infants and young children is not known. Moreover, as has been shown in a Swedish hypothyroid screening program [1], parents experience significant emotional trauma in feeling that their child has a congenital disorder.

In summary, congenital hypothyroidism represents a broad spectrum of disease anatomically and functionally. Thyroid scintigraphy helps differentiate the various forms of congenital hypothyroidism and elucidate severity and prognosis of the disease. Current techniques using I-123 allow rapid, accurate performance of thyroid scintigraphy in the neonate; total body radiation exposure is insignificant, being equivalent to that received in a single chest $\mathrm{x}$ ray film. Helping diagnose mild and transient hypothyroidism may decrease unnecessary treatment. It is only through thorough diagnostic testing before therapy in the immediate neonatal period and continued long-term follow-up after treatment that congenital hypothyroidism can be properly managed. Programs for detecting congenital hypothyroidism should incorporate diagnostic and follow-up features that are as rigorous as those for the screening process itself in order to realize their full potential.

\section{Summary}

Current newborn screening programs in California and most of the U.S. depend for diagnosis of congenital primary hypothyroidism on demonstrating an elevated thyrotropin (TSH) level in infants with the lowest 5\% to $10 \%$ of thyroxine $\left(\mathrm{T}_{4}\right)$ levels by filter-paper bloodspot test. The diagnosis of primary congenital hypothyroidism based on low $\mathrm{T}_{4}$ with high TSH fails to distinguish between transient hypothyroidism, ectopic or hypoplastic thyroid, athyrosis, dyshormonogenesis, and transient hyperthyrotropinemia. We screened 166,300 newborn infants for primary congenital hypothyroidism for 6.5 years and confirmed the diagnosis in 46 cases; none of

these patients had a goiter. Thyroid scintigraphy was performed in 40 with technetium- $99 \mathrm{~m}$ (Tc-99m) in the first eight cases tested and iodine-123 (I-123) in 29 of the last 32 cases. Fifteen infants were athyroid and seven had ectopic or hypoplastic glands; in 18 the thyroid gland appeared normal (present, normal location). Congenital hypothyroidism represents a spectrum of diseases from transient underactivity to complete absence of the thyroid gland. We recommend that, before starting treatment, a specific anatomic and functional diagnosis be confirmed by thyroid scintigraphy and other thyroid function tests.

Keywords: Congenital hypothyroidism, hypotyroidism, radionuclide imaging, thyroid diseases, thyroid function tests, thyroid scintigraphy.

\section{Zusammenfassung}

\section{Heterogenität der kongenitalen primären Hypothyreose} und Bedeutung der Schilddrüsenszintigraphie

In Kalifornien und den meisten anderen Staaten in Amerika beruht das gängige Neugeborenenscreening zur Erfassung einer kongenitalen primären Hypothyreose auf dem Nachweis eines erhöhten TSH-Spiegels bei niedrigen $\mathrm{T}_{4}$-Spiegeln. Die Bestimmung erfolgt aus Blutspots auf Filterpapier. Wird bei niedrigem $\mathrm{T}_{4}$-Wert und hohem TSH-Wert die Diagnose primäre kongenitale Hypothyreose gestellt, so wird nicht unterschieden zwischen einer transitorischen Hypothyreose, einer ektopischen oder hypoplastischen Schilddrüse, einer Athyreose, Hormonstörung und transitorischer Überproduktion von TSH. Bei 166300 Neugeborenen wurde ein Screening auf eine primäre kongenitale Hypothyreose durchgeführt; die
Kinder wurden 6,5 Jahre beobachtet. In 46 Fällen wurde die Diagnose bestätigt, wobei keines der Kinder einen Kropf hatte. Die Schilddrüsenszintigraphie wurde zunächst mit Technetium-99m (Tc-99m), später mit Jod123 (J-123) durchgeführt. 15 Kinder hatten eine Athyreose, 7 Kinder ektopische oder hypoplastische Drüsen. Bei 18 Kindern stellte sich die Schilddrüse völlig normal dar (nachweisbar, normaler Sitz). Die kongenitale Hypothyreose beinhaltet ein Spektrum verschiedener Erkrankungen von der vorübergehenden Unterfunktion bis zum totalen Fehlen der Schilddrüse. Bevor mit einer Behandlung begonnen wird, sollte die Diagnose hinsichtlich Anatomie und Funktion durch eine Schilddrüsenszintigraphie und andere Schilddrüsenfunktionstests bestätigt werden.

Schlüsselwörter: Darstellung mit Radionukliden, Hypothyreose, kongenitale Hypothyreose, Schilddrüsenerkrankungen, Schilddrüsenfunktionstests, Schilddrüsenszintigraphie. 


\section{Résumé}

Hétérogénéité de l'hypothyroïdie primaire congénitale: importance de la scintigraphie thyroïdienne

En Californie et dans la pluspart des E. U., les programmes de dépistage de routine chez le nouveau-né reposent, spour le diagnostic d'hypothyroïdie primaire congénitale, sur la mise en évidence de taux élevés de thyréotrophine (TSH) chez les enfants présentant des taux de thyroxine $\left(\mathrm{T}_{4}\right)$ abaissés de 5 à $10 \%$ sur le test des taches de sang sur papier filtre. Le diagnostic d'hypothyroïdie congénitale primaire, fondé sur une $T_{4}$ basse avec une "TSH élevée, ne permet pas de faire la distinction entre 1'hypothyroïdie transitoire, la thyroïdie ectopique ou hypoplasique, l'athyréose, la dyshormonogénèse et l'hyperthyréotrophinémie transitoire. Nous avons examiné 166300 nouveaux-nés pour dépister l'hypothyroïdie congénitale primaire pendant 6 ans et demi et nous avons confirmé le diagnostic 46 fois; aucun de ces patients n'avait de goitre. Nous avons réalisé une scintigraphie thyroïdienne chez 40 enfants, au technetium- $99 \mathrm{~m}$ (TC-99m) pour les 8 premiers cas, à l'iode-123 (I-123) pour 29 des 32 derniers cas. Quinze enfants présentaient une athyroïdie et sept avaient une glande ectopique ou hypoplasique; chez 18, la thyroïde apparaissait comme normale (présente et de localisation normale). L'hypothyroïdie congénitale représente un ensemble de maladies qui vont de l'hypoactivité jusqu'à l'absence complète de glande thyroïde. Nous recommandons qu'avant de débuter le traitement, on confirme un diagnostic spécifique anatomique et fonctionnel en effectuant une scintigraphie thyroïdienne et les autres tests fonctionnels thyroïdiens.

Mots-clés: Hypothyroïdie, hypothyroïdie congénitale, imagerie radio-nucléaire, maladies thyroïdiennes, scintigraphie thyroïdienne, tests de fonction thyroïdienne.

\section{References}

[1] BODEGÅRD G, K FYrö, A LARsson: Psychological reactions in 102 families with a newborn who has a falsely positive screening test for congenital hypothyroidism. Acta Paediatr Scand (Suppl) 304 (1983) 3

[2] Czernichow P, M Schlumberger, R Pomarede, $P$ FraGu: Plasma thyroglobulin measurements help determine the type of thyroid defect in congenital hypothyroidism. J Clin Endocrinol Metab 56 (1983) 242

[3] Dammacco F, A Dammacco, T Cavallo, S SanSONNA, N BAFUNDI, C ToRelli, E Frezza, F Vitale, D GRISETA: Serum thyroglobulin and thyroid ultrasound studies in infants with congenital hypothyroidism. J. Pediatr 106 (1985) 451

[4] FisHeR DA: Second international conference on neonatal thyroid screening: Progress report. J Pediatr 102 (1983) 653

[5] Fisher DA, JH Dussault, TP Foley JR, AH Klein, S LAFranchi, PR LARSEN, ML Mitchell, WH MURPHEY, PG WALFISH: Screening for congenital hypothyroidism: Results of screening one million North American infants. J Pediatr 94 (1979) 700

[6] Heyman S, JF Crisler JR, S Treves: Congenital hypothyroidism: I thyroidal uptake and scintigraphy. J Pediatr 101 (1982) 571

[7] JASKo IA, LV Dos Remedios, EJ Schoen: Benefits and risks of thyroid scintigraphy in congenital primary hypothyroidism. J Nucl Med Technol 12 (1984) 167
[8] Johanson A, R BLIzZARD: A syndrome of congenital aplasia of the alae nasi, deafness, hypothyroidism, dwarfism, absent permanent teeth, and malabsorption. J Pediatr 79 (1971) 982

[9] LafRanChI SH, WH MurPhey, TP Foley JR, PR LARSEN, NRM BUIST: Neonatal hypothyroidism detected by the Northwest Regional Screening Program. Pediatrics 63 (1979) 180

[10] LeVY HL, ML Mitchell: Regional newborn screening for hypothyroidism. Pediatrics 63 (1979) 340

[11] LiN WCW, LV Dos Remedios: A new economical method for determination of triiodothyronine $\left(T_{3}\right)$ uptake using talc tablets. J Nucl Med Technol 6 (1978) 207

[12] Mitchell ML, PR Larsen, HL Levy, AJE BeNNETT, MA MADOFF: Screening for congenital hypothyroidism: Results in the newborn population of New England. JAMA 239 (1978) 2348

[13] PÖYHÖNEN L, HL LeNKo: Ultrasonography in congenital hypothyreosis. Acta Paediatr Scand 73 (1984) 523

[14] Price DA, RM Ehrlich, PG Walfish:Congenital hypothyroidism: Clinical and laboratory characteristics in infants detected by neonatal screening. Arch Dis Child 56 (1981) 845

[15] SCHOEn EJ, R FefFerman: Screening for congenital hypothyroidism. J Pediatr 96 (1980) 171

Received October 30, 1985. Accepted July 9, 1986.

Dr. Edgar J. Schoen

Department of Pediatrics

Kaiser Permanente Medical Center

280 W. MacArthur Blvd.

Oakland, CA 94611, U. S. A. 